\title{
The road to hell: State violence against children in postwar New Zealand
}

\author{
Elizabeth Stanley, 2016 \\ Auckland University Press, Auckland, NZ \\ ISBN: 978186940854 1, pp.280, paperback, NZ\$ 45
}

$\mathrm{I}$ n this important book Elizabeth Stanley tells the stories of 105 survivors of state care. The participants in her research spent time as state wards when they were children and/or young people. The book's emphasis is on the state run, or state funded, institutions which were in existence after the second world war until the end of the twentieth century, when deinstitutionalisation took effect. Access to participants was gained through a law firm who represented the participants' claims against the state for abuse they suffered in state care. Stanley notes some limitations with the method of accessing participants. It has potentially skewed the representation of survivors: the majority of participants were men and more than half identified as European/Pākehā. While significant numbers of women and nonEuropean/Pākehā were in care during this time period men and European/Pākehā were the majority of claimants. Alongside the demographic bias there was a bias of experience as all the participants in Stanley's book had taken legal action against the state, this was not balanced with other experiences which may have been positive.

In a coherent and logical way Stanley outlines the thinking of the post war time period in which so many children found themselves in institutions and this provides a context, but not excuse, for the actions of bureaucrats towards the children, young people and their whanau and families. As a society, an "out of sight, out of mind" approach was taken towards state wards during this time. Denial continues to permeate the state response to victims today, an issue which Stanley addresses in the last chapter of the book.

The order of The Road to Hell follows the journey of children and young people through the state welfare system and ends by considering their transition out of care and the impact their childhood experiences and abuse had on their adult lives. At the start of the book how and why children were placed in care of the state is outlined through the use of quotes from individual stories as well as explanations of the wider context. It is disturbing how easily children slipped into care, the lack of voice for them and the minimal involvement of their whanau or families, contact was discouraged. State involvement in children's lives and their removal from kin care was challenged by the Pūao-te-Āta-tū report (Department of Social Welfare, 1986) however the rhetoric and actions of our current government indicate we are returning to similar practices, underpinned by an ideology similar to that of the post war period.

The experiences of participants in care is described. Everyday life and routines are depicted, alongside stories of abuse at the hands of individual staff members and structural violence. Some abuse discussed is emotional, such as public humiliation, while other stories describe sexual and physical abuse perpetrated by individuals or groups. Systemic abuse, such as the use of secure units and forced psychiatric treatment is charted. State neglect is examined; most of the participants left state care with minimal education and limited skills for daily life. Lack of education and life skills affected 
participants' ability to find employment, or reasonable employment, sustain relationships and parent their own children. Substance abuse among participants is common, it is an accessible way to deal with the residue of pain and emptiness from childhood.

Stanley finishes the book by considering "where to from here" for Aotearoa New Zealand. She portrays the processes which have been used to deal with the wrongs of the past and all are found wanting, although Stanley does consider the Confidential Listening and Assistance Service was the most effective process despite lack its authority and inability to compel action. A recommendation is made to establish an independent commission to expose the victimization of ex state wards and to ensure effective redress for them. The need for action on this is urgent as some of Stanley's participants were born in the 1940s.

The author, who is a criminologist, provides a clear understanding of the way in which children in state care were subjected to abuse, violence, neglect and humiliation during the second half of last century. It was my interest in social history which drew me to review this book as well as my experience in the 1980s as a student on placement at Kohitere Boys Home, one of the institutions described in Stanley's book. What I did not consider about reviewing this book was the emotional impact the stories would have on me and the memories resurfacing of stories I heard while on placement, such as the boys joking about "stomping", a form of collective violence used to initiate newcomers. I found it a harrowing read; the childhood experiences of suffering of the participants are told in all their horror.

Before I had finished reading this book I was recommending it. I found it incredibly well researched and easy to read. The authors writing style is clear, coherent and interesting. Stanley incorporates quotes throughout the book which integrates the voice of participants. I think this book should be read widely, particularly by decision makers who are restructuring Child, Youth and Family to ensure we don't repeat the mistakes of the past.

\section{Reference}

Ministerial Advisory Committee on a Māori Perspective for the Development of Social Welfare. (1986). Pūao-te-Āta-tū. The report of the Ministerial Advisory Committee on a Māori perspective for the Department of Social Welfare. Wellington, NZ: Department of Social Welfare 